УДК 327.7 : 005.591.4-047.44

DOI: 10.26693/ahpsxxi2020.02.027

\title{
РЕФОРМУВАННЯ РАДИ БЕЗПЕКИ ООН У ПЕРІОД ОДНОПОЛЯРНОСТІ (1991-2001 рр.)
}

\author{
Віктор Мащенко, \\ e-mail: mashchenkovd@gmail.com \\ ORCID: https://orcid.org/oooo-ooo2-0962-3963 \\ Чорноморсъкий національний університет імені Петра Могили, \\ Украӥна, 54оо3, м. Миколаӥв, вул. 68 Десантників, 10
}

Реформування Ради Безпеки Організацї Об’єднаних Націй є одним з ключових питань подальшого стабільного та прогнозованого розвитку міжнародного середовища. Після розвалу СРСР $і$ закінчення «холодної війни» це стало зрозуміло міжнародній спільноті, тому, зазначене питання почало активно обговорюватись на Генеральних Асамблеях. У результаті чого була створена спеціальна Робоча Група для розгляду, систематизацій та формулювання пропозицій щодо трансформацї у Раді Безпеки.

Ключові слова: ООН, Рада Безпеки, реформування, Генеральна Асамблея, Робоча Група

Постановка проблеми. На сучасному етапі розвитку міжнародних відносин дедалі чіткіше проявляється потреба оперативної та скоординованої протидії загрозам, які носять глобальний характер. Дати ефективну відповідь на ці загрози та виклики можуть тільки механізми, що діють у рамках легітимних структур, що володіють достатнім моральним авторитетом для того, щоб їх рішення носили загальновизнаний характер, а не викликали звинувачення у свавіллі і подвійних стандартах .

Традиційно вважалося, що ООН є єдиною універсальною організацією світової спільноти, вищим носієм та охоронцем сучасного міжнародного права, яка користується найвищим моральним авторитетом. Але 3 певного часу вона була поставлена під сумнів.

Сьогодні не тільки фахівці-міжнародники, а й представники неурядових організацій висувають ідеї докорінної реформи ООН і радикального перегляду їі Статуту. Критика на адресу ООН пов'язана з її надмірною бюрократизацією, паралелізмом у функціях багатьох структур. Крім цього, ООН звинувачують у тому, що вона більше реагує на кризи, ніж запобігає їм. Виборчий інтерес ООН до конфліктів у різних регіонах світу дає підстави стверджувати про наявність в ії діяльності подвійних стандартів.

Однак ООН все-таки має достатній потенціал для перетворення в успішно функціонуючий політичний інструмент вирішення світових проблем, у визнаного гаранта глобальної та регіональної стабільності. Разом з тим, для досягнення цієї мети необхідно провести реформи, які зачіпають основні органи та інститути ООН. Основною, але у той же час найбільш складною та суперечливою, є реформа Ради Безпеки.

3 тих пір як була створена Рада, загрози та виклики міжнародному миру і безпеці змінилися, також як і розподіл сил між членами Організації. Як відомо, ООН створювалася як організація країн-переможниць у Другій світовій війні. На Раду Безпеки покладалася головна відповідальність за підтримання миру і безпеки народів. При визначенні складу Ради Безпеки творці ООН керувалися, перш за все, існуючим розкладом сил у світі, тому можна стверджувати, що склад Ради на той момент вірно відбивав міжнародну політичну ситуацію.

Членський склад Ради Безпеки розширювався за весь час всього один раз (у 
1963 р.) - 311 до 15 членів ${ }^{1}$. Причому це збільшення стосувалося тільки категорії непостійних членів, а загальне число країн-учасниць ООН за час існування Організації зросло 351 до 193 держав. Тобто кількість учасників Ради Безпеки збільшилася всього на $36 \%$, у той час як загальна чисельність країн-членів $\mathrm{OOH}$ зросла в 3,7 рази. У 1945 р. членський склад Ради Безпеки представляв 21,6\% країн-учасниць ООН, в 1963 р. - 13\%; наразі - менше 8\% членського складу Організації. Таким чином, одним з найскладніших питань реформування Ради Безпеки є розширення його складу.

Ступінь наукової розробки проблеми. На сьогоднішній день питання важливості реформування Ради Безпеки ООН все частіше підіймається у наукових колах як вітчизняних, так й закордонних. Серед українських авторів варто виділити праці I. Червінки ${ }^{2}$, Л. Дорош і С. Охремчука3, які акцентують увагу на важливості реформування Ради Безпеки ООН з метою покращення ㄲï діяльності в питанні забезпечення стабільності та миру у світі. Грунтовними є напрацювання й закордонних дослідників. Серед них варто виокремити праці М. Гоудліна4, М. Франда5, В. Заємскі ${ }^{6}$, які також наголошують на процесі реформування даної організації та визначають наявні проблеми у повноцінній іiі дієвості.

Виклад основного матеріалу. Вперше проблема справедливого представництва в Раді Безпеки і розширенні його членського складу була включена до порядку денного ООН у 1979 р. (34 сесія ГА). У ході 48-ї Генеральної Асамблеї в 1993 р. було вирішено «заснувати Робочу групу відкритого складу для розгляду всіх аспектів питання про розширення членського складу Ради Безпеки та інших питань, що стосуються Ради Безпеки»7.

Дебати показали, що у Робочій групі відкритого складу досягнуто згоди щодо необхідності підвищення ефективності Ради Безпеки шляхом розширення його членського складу з метою більш точного відображення важливих змін, що відбулися на міжнародній арені, включаючи істотне збільшення числа членів $\mathrm{OOH}$, особливо за рахунок країн, що розвиваються ${ }^{8}$. Дебати продемонстрували, що існує згода щодо необхідності переглянути склад Ради, методи його роботи й інші питання, що стосуються іï функціонування. Було визнано, що у роботі з реформи Ради Безпеки слід керуватися принципами суверенної рівності всіх членів ООН і справедливого географічного розподілу та представництва, а також концепціями гласності, законності, ефективності та результативності9.

\footnotetext{
${ }^{1}$ Нью-Йорк. Генеральная Ассамблея ООН. Резолюция. (1963, 17 декабря). Вопрос о справедливом представительстве в Совете Безопасности и в Экономическом и Социальном Совете. (1991 (XVIII)), 1.

2 Червінка, I. (2016). Перспективи реформування ООН у контексті обрання нового Генерального секретаря. Політичні науки, 2, 69-74.

3 Дорош, Л., Охремчук, С. (2015). РБ ООН у сучасних умовах: до проблеми пошуку варіантів реформування. Humanitarian vision, 2, 19-26.

4 Goulding, M. (1993). The evolution of United Nations peacekeeping. International Affairs. 69, 3, 451-464.

5 Franda, M.F. (2006). The United Nations in the Twenty-First Century: Management and Reform Processes in a Troubled Organization. Rowman \& Littlefield Publishers, Inc.

${ }^{6}$ Zaemsky, V.F. (2008). Theory and practice of UN peacekeeping. Institute of International Relations (University) of the Ministry of Foreign Affairs of Russia.

7 Нью-Йорк. Генеральная Ассамблея ООН. Резолюция (1993, 3 декабря) Справедливое представительство в Совете Безопасности и расширении его членского состава. (A/Res/48/26), 2.

${ }^{8}$ Нью-Йорк. Генеральная Ассамблея ООН. Официальные отчеты (1996). Доклад Рабочей группы открытого состава по вопросу о справедливом представительстве в Совете Безопасности и расширении его членского состава и других вопросов, связанных с Советом Безопасности. (А/49/47), 5 .

9 Нью-Йорк. Генеральная Ассамблея ООН. Повестка дня (1995, 13 сентября). Вопрос о справедливом представительстве в Совете безопасности и расширение его членского состава и связанные с этим вопросы. (A/49/965), 10.
} 
Було висловлено низку пропозицій щодо оптимального складу і чисельності Ради. Окремі делегації виступали за збільшення числа як постійних, так і непостійних членів Ради. Інші підтримали пропозицію про збільшення лише однієї з існуючих категорій, при цьому відкинули пропозицію про збільшення тільки числа постійних членів. Висувалися ідеї створення нової категорії чи нових категорій, нового типу або нових типів членів. Інші делегації вказали, що масштаби збільшення однієї категорії торкнуться питання збільшення іншої категорії. Велика група делегацій відзначила, що, якщо немає спільної думки щодо інших категорій членського складу, розширення складу має у даний час стосуватися лише категорії непостійних членів.

Все більшу підтримку почала набувати пропозиція про встановлення чисельності Ради у межах 20-25 членів. Багато з тих, хто виступав за збільшення числа постійних членів, пропонували збільшити його на п'ять місць. Велика група делегацій запропонувала збільшити склад Ради щонайменше до 26 членів ${ }^{10}$.

Розглядаючи питання про постійних членів Ради, більшість делегацій зосередили свою увагу на тому, чи слід було збільшувати чисельність категорії постійних членів і якщо так, то як саме. Низка делегацій наполягала на тому, що принцип рівного географічного представництва вимагає збільшення числа постійних членів, що мав відображати склад ООН, інші виступили за надання місць постійних членів тим державам, які зазнали значних глобальних змін в економічному та політичному напрямах після 1945 р. і були спроможні нести глобальну відповідальність за підтримання міжнародного миру та безпеки. На їх думку, збільшення числа постійних членів мало зміцнити ООН і підвищити їі юридичний статус, наблизивши Організацію до тогочасних глобальних реалій.

Від делегацій звучали виступи проти розширення цієї категорії членів на тій підставі, що призначення нових постійних членів суперечитиме принципу демократизації у міжнародних відносинах. На їхню думку, в Сан-Франциско у 1945 р. була допущена помилка при створенні категорії постійних членів Ради Безпеки і вона не повинна була повторитися. Багато делегації рішуче заперечували проти збільшення числа постійних членів з тих причин, що це суперечило принципу суверенної рівності всіх держав-членів ООН і могло посилити невідповідність, вже в існуючій Раді Безпеки. Вони також вказали, що призначення нових постійних членів не сприятиме підвищенню дієвості й ефективності Ради. Окремі делегації заявили, що розширення категорії постійних членів, яке лише призведе до збільшення в Раді числа промислово-розвинених країн, є неприйнятним. Інші вказували на необхідності періодичного перегляду складу постійних членів, а деякі з них виступили за встановлення процедури припинення дії статусу постійного члена ${ }^{11}$.

Були висловлені різні думки з приводу необхідності вироблення критеріїв для відбору нових постійних членів ${ }^{12}$. Низка делегацій поставили під сумнів необхідність вироблення критеріїв, оскільки це питання для політичного обговорення та вирішення. Інші делегації запропонували низку критеріїв, у тому числі критерії, що містяться в пункті 1 статті 23 Статуту, які застосовуються лише для відбору непостійних членів: належне представництво країн, що розвиваються; чисельність населення;

\footnotetext{
${ }^{10}$ Нью-Йорк. Генеральная Ассамблея ООН. Официальные отчеты (1998). Доклад Рабочей группы открытого состава по вопросу о справедливом представительстве в Совете Безопасности и расширении его членского состава и других вопросов, связанных с Советом Безопасности. (A/50/47/Rev.1), 33.

${ }^{11}$ Нью-Йорк. Генеральная Ассамблея ООН. Официальные отчеты (1997). Доклад Рабочей группы открытого состава по вопросу о справедливом представительстве в Совете Безопасности и расширении его членского состава и других вопросов, связанных с Советом Безопасности. (А/51/47), 20.

12 Нью-Йорк. Генеральная Ассамблея ООН. Официальные отчеты (1998). Доклад Рабочей группы открытого состава по вопросу о справедливом представительстве в Совете Безопасности и расширении его членского состава и других вопросов, связанных с Советом Безопасности. (A/50/47/Rev.1), 38.
} 
масштаби економіки і майбутній потенціал; готовність робити внесок у підтримання миру, політичну й економічну діяльність ООН та їх незмінна підтримка, фінансовий внесок в $\mathrm{OOH}$, в тому числі в добровільні фонди і програми. Низка делегацій з числа тих, які виступали за збільшення числа постійних членів, також прямо або побічно вказали на ряд країн з числа розвинених і країн, що розвиваються, які, на їхню думку, могли бути кандидатами до складу постійних членів.

Думки також розділилися з питання про те, як у випадку розширення числа постійних членів здійснювати відбір таких членів. Низка делегацій виступали за глобальний підхід, відповідно до якого нових постійних членів мала обирати Генеральна Асамблея, по можливості на основі узгодженої формули регіонального розподілу. Інші делегації висловили думку про те, що першочергова відповідальність за відбір повинна лежати на регіональних групах Генеральної Асамблеї13.

Було висловлено рішучу підтримку пропозиції про збільшення числа непостійних членів Ради з урахуванням необхідності забезпечення справедливого географічного представництва. Низка делегацій зазначили, що членський склад ООН значно розширився після останнього збільшення числа постійних членів Ради у 1965 р., і це вимагає подальшого розширення складу даної категорії. Завдяки цьому підвищиться законність дій Ради від імені всіх членів, як того вимагає положення пункту 1 статті 24 Статуту.

Багато делегації наполягали на тому, що збільшення числа непостійних членів повинно бути обмеженим, 3 тим щоб це негативно не позначилося на дієвості й ефективності Ради. Інші, навпаки, говорили, що таке збільшення негативно не позначиться на ефективності роботи органу, а, навпаки, може призвести до підвищення дієвості Ради. Вони також підкреслили, що розширення членського складу цієї категорії розширить можливості для більшого числа держав брати участь у роботі Ради відповідно до принципу справедливого географічного розподілу, що сприятиме подальшій реорганізації ООН та її головних органів ${ }^{14}$.

Рішучу підтримку отримали критерії, що містяться в пункті 1 зі Статті 23, а саме участь членів у підтримці міжнародного миру і безпеки, у досягненні інших цілей Організації, справедливий географічний розподіл. Тим не менш, деякі делегації висловили занепокоєність тим, що ці критерії не дають ефективних гарантій того, що всі держави-члени ООН мали рівну можливість брати участь у роботі Ради. У цілому було визнано, що слід розширити представництво в Раді країн Азї, Африки, Латинської Америки і Карибського басейну. Була поставлена під сумнів справедливість тогочасного представництва Східної Європи ${ }^{15}$.

Окрім того, була висловлена думка про те, що держави-члени ООН не мали рівних можливостей участі у роботі Ради Безпеки; деякі більші держави часто повторно обиралися до Ради, у той час як низка інших держав-членів ООН ніколи не брали участі в їі роботі. Деякі делегації вказали на відсутність однаковості у відборі регіональними групами $\mathrm{OOH}$ кандидатів у непостійні члени. У зв’язку з цим з посиланням на систему ротації, яка застосовується Групою африканських держав на відміну від практики інших груп, було запропоновано уніфікувати процедуру відбору в ООН 3 метою забезпечити однаковий режим у всіх регіонах. Було також запропоновано впорядкувати існуючу практику більш регулярного відбору окремих держав у непостійні члени Ради. Це передбачало формулу, згідно з якою певні узгоджені поіменно

13 Нью-Йорк. Генеральная Ассамблея ООН. Официальные отчеты (1999). Доклад Рабочей группы открытого состава по вопросу о справедливом представительстве в Совете Безопасности и расширении его членского состава и других вопросов, связанных с Советом Безопасности. (А/53/47), 35.

14 Нью-Йорк. Генеральная Ассамблея ООН. Официальные отчеты (1998). Доклад Рабочей группы открытого состава по вопросу о справедливом представительстве в Совете Безопасности и расширении его членского состава и других вопросов, связанных с Советом Безопасности. (A/50/47/Rev.1), 7.

15 Ibidem, 8. 
держави мали обиратися на додаткові місця непостійних членів Ради частіше, ніж інші держави. Були висловлені думки як на підтримку, так і проти скасування заборони на негайне переобрання непостійних членів, що міститься у пункті 2 статті 23. Низка делегацій вказали, що це питання залежить від інших аспектів пропонованої комплексної угоди ${ }^{16}$.

Були висловлені пропозиції щодо створення нової категорії або нового типу членів. Деякі з цих пропозицій стосувалися розподілу місць, що підлягають заняття державами, які братимуть участь у роботі Ради довше і/або на більш частій основі, ніж існуючі непостійні члени. Деякі з них передбачали, що одне місце будуть займати дві або більше держав, або регіональна група чи організація. Деякі делегації вказали на необхідність збереження лише двох категорій, передбачених у Статуті.

Було також висловлено альтернативну пропозицію про збільшення числа непостійних членів (пункт 10). Висловлювалася занепокоєність 3 приводу того, що нова категорія або категорії і низка інших пропозицій, що стосувалися розширення складу Ради, можуть привести до переведення більшості держав-членів у категорію третього розряду або до обмеження їх можливості вибирати склад Ради. Низка делегацій також побажали залишити ці пропозиції в якості варіантів для подальшого розгляду17.

Було проведено широке обговорення процедур голосування у Раді Безпеки, особливо з питання про право вето. Багато делегацій підкреслили необхідність проведення реформи щодо права вето. Велике число делегацій вважали право вето анахронізмом і виступали за те, щоб воно було скасованим. Вони вказали, що саме існування права вето є постійною загрозою для процесу прийняття рішень у Раді Безпеки.

Противники права вето вказували, що воно $є$ в корені недемократичним і що його існування суперечить принципу суверенної рівності всіх держав. Деякі делегації відзначили, що воно серйозно заважає роботі Ради Безпеки, особливо упродовж перших чотирьох десятиліть існування ООН. Прихильники права вето стверджували, що воно ніколи не розглядалося як демократичний засіб, а як корисний інструмент, що сприяв збереженню єдиної позиції постійних членів і забезпечував постійну участь у роботі Організації основних держав. На їхню думку, право вето є корисним засобом, що допомагає гарантувати, щоб прийняті Радою рішення були збалансованими, а також забезпечує стабільність і запобігає конфліктам між основними державами, які могли б підірвати колективну безпеку $\mathrm{OOH}^{18}$.

Низка делегацій запропонували обмежити право вето у його масштабах і випадках використання. Пропоновані обмеження включали: скасування використання права вето при прийнятті рішень, що стосувалися прийому нових держав-членів $\mathrm{OOH}^{19}$.

Низка делегацій вказували на те, що відповідно до пункту 2 статті 27 вето не поширюються на процедурні питання i, що необхідно провести дослідження з метою визначення рішень, які слід вважати процедурними за своїм характером. Було підкреслено, що деякі із заходів по обмеженню масштабів і випадків використання вето можуть не вимагати внесення поправок до Статуту, а можуть бути здійснені шляхом перегляду Тимчасових правил процедури Ради Безпеки, нинішньої практики в Раді та резолюцій Генеральної Асамблеї.

\footnotetext{
${ }^{16}$ Нью-Йорк. Генеральная Ассамблея ООН. Повестка дня (1995, 13 сентября). Вопрос о справедливом представительстве в Совете безопасности и расширение его членского состава и связанные с этим вопросы. (А/49/965), 12.

${ }_{17}^{17 ь ю-И ̆ о р к . ~ Г е н е р а л ь н а я ~ А с с а м б л е я ~ О О Н . ~ О ф и ц и а л ь н ы е ~ о т ч е т ы ~(1999) . ~ Д о к л а д ~ Р а б о ч е и ̆ ~}$ группы открытого состава по вопросу о справедливом представительстве в Совете Безопасности и расширении его членского состава и других вопросов, связанных с Советом Безопасности. (A/53/47), 44.

18 Ibidem, 46.

19 Нью-Йорк. Генеральная Ассамблея ООН. Официальные отчеты (1997). Доклад Рабочей группы открытого состава по вопросу о справедливом представительстве в Совете Безопасности и расширении его членского состава и других вопросов, связанных с Советом Безопасности. (A/51/47), 21.
} 
Окремі делегації виступили проти будь-яких обмежень застосування вето. Вони також вказали, що існує низка серйозних юридичних і політичних проблем, пов'язаних з обмеженням випадків використання вето, і що бажано не витрачати занадто багато часу на обговорення вето у його нинішній формі. Інші делегації відзначили, що останнім часом постійні члени все рідше застосовують право вето, і на їхню думку, це є позитивним зрушенням ${ }^{20}$.

Були висловлені різні погляди щодо того, чи потрібно надавати право вето можливим новим постійним членам. Прихильники цього виступили проти створення нової категорії постійних членів другого класу. Зазначивши, що надання однакового режиму старим і новим постійним членам є важливим принципом. Крім того, низка делегацій стверджували, що нинішній дисбаланс у Раді Безпеки був би лише частково скорегований, якби новим постійним членам було відмовлено у праві вето. Делегації, які виступали проти надання права вето новим постійним членам, вважали, що це буде суперечити принципу суверенної рівності держав і духу співробітництва у системі колективної безпеки. Противники такого розширення побоювалися, що це може завдати шкоди ефективності та дієвості Ради Безпеки і може закріпити існуючий регіональний дисбаланс.

Висловлювалося міркування про те, що нові постійні члени можуть виступати 3 односторонніми заявами щодо своїх намірів обмежити використання права вето. Ця пропозиція отримала підтримку з боку деяких делегацій, однак інші делегації висловили сумніви щодо фактичної дієвості таких політичних декларацій. На думку окремих делегацій, питання про надання права вето може бути вирішене лише після досягнення згоди щодо того, чи будуть введені до складу Ради нові постійні члени і хто буде займати ці місця.

Деякі делегації послалися на привілеї де-факто, якими користуються постійні члени, включаючи постійне представництво у таких органах $\mathrm{OOH}$, як Міжнародний Суд, Економічна і соціальна рада та Генеральний комітет Генеральної Асамблеї. Ці делегації запропонували провести розгляд питання як про привілеї постійних членів, так і про те, чи слід ці привілеї надавати новим постійним членам. Інші делегації поставили існування таких привілеїв під сумнів, вказавши, що постійні члени Ради Безпеки завжди повинні проходити через процедуру обрання в інші органи $\mathrm{OOH}^{21}$.

Деякі делегації звернули увагу на необхідність розгляду питання про згаданий в пункті 3 статті 27 голосів більшості для розширеного складу Ради і виступали за збереження пропорційної аналогічної цифри ${ }^{22}$.

Багато делегацій вітали пропозицію про те, що чисельність і склад, а також право вето й інші процедури голосування Ради Безпеки повинні періодично переглядатися. 3 іншого боку, висловлювалися застереження у зв’язку з концепцією періодичного перегляду. 3 точки зору деяких делегацій система періодичного перегляду була б рівнозначна визнанню провалу процесу реформ, тоді як інші делегації висловили припущення про те, що періодичні огляди приведуть до виникнення ситуації, в якій деякі держави будуть постійно займатися виборними кампаніями. Однак окремі делегації вказали на те, що концепція перегляду була невід’ємною частиною ООН з самого початку і може бути активізована шляхом застосування статті 109 Статуту ООН.

Висновки. Таким чином по закінченню «холодної війни» в ООН почалися активні розробки планів реформування Ради Безпеки. Вже у середині 90-х років XX ст.

${ }^{20}$ Нью-Йорк. Генеральная Ассамблея ООН. Официальные отчеты (2001). Доклад Рабочей группы открытого состава по вопросу о справедливом представительстве в Совете Безопасности и расширении его членского состава и других вопросов, связанных с Советом Безопасности. (А/55/47), 84.

${ }^{21}$ Ibidem, 92.

22 Нью-Йорк. Генеральная Ассамблея ООН. Официальные отчеты (1998). Доклад Рабочей группы открытого состава по вопросу о справедливом представительстве в Совете Безопасности и расширении его членского состава и других вопросов, связанных с Советом Безопасности. (A/50/47/Rev.1), 78. 
були точно сформульовані головні кризові точки структури. Абсолютно точно прогнозовані варіанти можливих криз членами делегацій Робочої Групи та запропоновані варіанти їх вирішення. Однак, через надмірну забюрократизованість структур $\mathrm{OOH}$ і небажання головних гравців міжнародної політики щось змінювати, реальних реформ не відбулося.

Враховуючи подальший розвиток існуючих проблем універсальної організації та ії органів є декілька напрямків можливих реальних змін: 1) припинення безрезультатних обговорень у рамках вже існуючих парадигм реформи як зміна кількості представників і перегляд права вето; 2) відмова від класичного сприйняття акторів міжнародних відносин у рамках $\mathrm{OOH}$; 3) максимальна легітимізація латентних впливів некласичних акторів.

\section{REFERENCES}

Chervinka, I. (2016). Perspektyvy reformuvannia OON u konteksti obrannia novoho Heneralnoho sekretaria. [Prospects for UN reform in the context of the election of a new Secretary General]. Politychni nauky, 2, 69-74 [in Ukrainian].

Dorosh, L., Okhremchuk, S. (2015). RB OON u suchasnykh umovakh: do problemy poshuku variantiv reformuvannia. [UN Security Council in modern conditions: to the problem of finding reform options]. Humanitarian vision, 2, 19-26 [in Ukrainian].

Franda, M.F. (2006). The United Nations in the Twenty-First Century: Management and Reform Processes in a Troubled Organization. Rowman \& Littlefield Publishers, Inc. [in English].

Goulding, M. (1993). The evolution of United Nations peacekeeping. International Affairs, 69, 3, 451-464 [in English].

Zaemsky, V.F. (2008). Theory and practice of UN peacekeeping. Institute of International Relations (University) of the Ministry of Foreign Affairs of Russia [in English].

Victor Mashchenko,

Petro Mohyla Black Sea National University, Mykolaiv, Ukraine

ORCID: https://orcid.org/oooo-0oo2-0962-3963

\section{Reform of the UN Security Council in the period of uniform polarity (1991-2001)}

At the present stage of international relations are becoming increasingly evident need prompt and coordinated counter threats are global. Only mechanisms operating within legitimate structures with sufficient moral authority to ensure that their decisions are universally recognized and not provoke accusations of arbitrariness and double standards can provide an effective response to these threats and challenges.

Traditionally it was believed that the UN is the only universal organization of the world community, the supreme bearer and guardian of modern international law and as such enjoys the highest moral authority for some time has been questioned.

Currently, not only international experts, but also representatives of nongovernmental organizations put forward the idea of radical reform of the UN and a radical revision of its Charter. UN criticism related to its excessive bureaucratization, parallelism in the functions of many structures. In addition, the UN is accused of being more responsive to crises than preventing them. The UN's interest in conflicts in different regions of the world gives grounds to claim the existence of double standards in its activities.

However, the UN still has sufficient potential to become a successfully functioning political tool for solving world problems, a recognized guarantor of global and regional stability. At the same time, to achieve this goal, it is necessary to carry out reforms that affect the main bodies and institutions of the United Nations. Basic, but at the same time the most complex and controversial is the reform of the Security Council.

Since the establishment of the Council, threats and challenges to international peace 
Acta de Historia \& Politica: Saeculum XXI

and security have changed, as has the distribution of power among the members of the Organization. As you know, the UN was conceived as an organization of victorious countries in World War II. The Security Council had the primary responsibility for maintaining the peace and security of the peoples. In determining the composition of the Security Council, the founders of the UN were guided primarily by the existence of forces in the world, therefore, it can be claimed that the composition of the Council at that time correctly reflected the international political situation.

Keywords: UN, Security Council, reform, General Assembly, Working Group 